\title{
The Asian Infrastructure Investment Bank and Status-Seeking: China's Foray into Global Economic Governance
}

\author{
Hai Yang ${ }^{1}$ (D)
}

Received: 15 April 2016/Accepted: 5 September 2016/Published online: 20 October 2016

(C) Fudan University and Springer Science+Business Media Singapore 2016

\begin{abstract}
Despite the long-standing debate on the rise of China, there has been relatively little attention to the country's status concerns. This article therefore examines how China sought an enhanced international status by looking into the illustrative case of the Asian Infrastructure Investment Bank (AIIB). To this end, it employs the social identity theory (SIT) framework applied to international relations (IR), in conjunction with additional insights into institutional innovation. In the IR context, SIT posits that an aspiring state resorts predominantly to one of the three status-seeking strategies-social mobility, social competition and social creativity, i.e., emulating or competing with established powers, or attempting to achieve prestige on a new dimension. As to institutional innovation, it is introduced as a construct to understand the crystallisation of social creativity in the AIIB. By virtue of analysing primary sources and secondary literature, the research at hand finds that in the case of the AIIB China adopted largely, albeit not exclusively, the social creativity strategy to mitigate the doubt of the West and boost the legitimacy of the bank. Specifically, Beijing followed the relevant rules of the game in the institutionbuilding process and presented as a legitimate addition the quintessential statusseeking initiative-partly born out of exasperations with the existing architecture. The case study on such a noteworthy institution-building effort can shed light on the underlying rationales and wider implications of similar China-backed structures and, relatedly, the strategic thinking of the Chinese leadership to seek a greater international status.
\end{abstract}

Keywords China · AIIB - Status-seeking - Global economic governance · Institutional innovation

Hai Yang

hai.yang@soc.kuleuven.be

$1 \quad$ Parkstraat 45, Box 3602, 3000 Leuven, Belgium 


\section{Introduction: China in Quest of Great-Power Status and the AIIB}

With its phenomenal economic growth over the past few decades, China has been seeking great-power status relative to that of other major powers (Larson 2015). Bolstered by its enhanced position after the 2008 global financial crisis, Chinese foreign policy aiming to redefine the country's regional and international role has decidedly continued apace (Chen 2014; Swaine 2010; Yan 2014). More recently, China has redoubled its efforts in global economic governance by undertaking a series of high-profile institution-building actions, seen by many as a clear statement of intent from Beijing that it desires to challenge American supremacy (Shapiro 2015) and shape new trading and investment rules in Asia (Kahn 2015). In the latest case of the AIIB - a newly founded multilateral lender, China played a decisive role over the course of 2 years that culminated in the successful establishment and official launch of the institution in mid-January 2016. Against substantial headwinds from the (US), Beijing brought together 57 countries as the AIIB's members, including a host of the superpower's staunch allies in Europe and Asia-Pacific.

A number of works have discussed the noteworthy China-led multilateral, looking at its institutional features, prospects and challenges (Chin 2016; Humphrey 2015; Greenwood 2016), potential impacts on the Bretton Woods and in particular global development finance (Kawai 2015; Liao 2015; Reisen 2015; Subacchi 2015) and, most of all, the multiplicity of rationales driving China to initiate the bank (Callaghan and Hubbard 2016; Dollar 2015; Ren 2016; Sohn 2015; Xing 2016). While published literature tends to dwell on the institution per se and to approach China's incentives from a rationalist perspective, this paper turns to the underlying ideational motivations and argues that at the core of the AIIB lies the enduring search of the Middle Kingdom for a greater status in its return to a major global power. On the one hand, the AIIB materialised in part because of the stillsmouldering grievances of China and other developing countries about their disproportionate representation and the glacial pace of governance reforms in the Bretton Woods system. On the other hand, by offering a real alternative, the AIIB simultaneously injects an increasing sense of urgency to reform the decade-old system in favour of emerging powers and give the largest shareholder China greater leeway to advance its unvarnished worldview on global economic governance (Renard 2015; Ujvari 2016). For nearly a decade preceding the AIIB, the US insisted that China stop freeriding the liberal system and act as a 'responsible stakeholder' by taking on more responsibilities (Nye 2013). Ironically, after China initiated the AIIB - a justifiable answer to the earlier criticism, senior US officials openly lobbied allies and partners to shun the project, presumably on the grounds that the AIIB would pose a threat to its Bretton Woods counterparts and precipitate a 'race to the bottom' in light of Beijing's poor track record in lending standards (Pollack 2015). While a variety of major Western economies opted to participate and shape the rules from inside, the US and Japan remain on the sidelines wary of China's ulterior motive to use the new lender for narrow economic or political ends.

Notwithstanding the initial apprehensions of Washington and Tokyo about the AIIB's credibility and competence to embody and uphold governance standards, 
they seem to have overplayed the hypothetically deleterious impacts of the Chinainitiated institution on the incumbent international system. Ostentatious as it may sound, Beijing has legitimate grounds for building a regional financial institution to complement the overstretched World Bank (WB) and Asian Development Bank (ADB) and to jointly close the wide financing gaps in Asian infrastructure (Bhattacharyay 2010; Elek 2014). Both the WB and ADB presidents welcomed the creation of the bank and inked co-financing framework agreements with the AIIB. Equally, presupposing the endgame of the AIIB is to fragment the current architecture seems to run counter to the changing realities that attest to Beijing's will and ability to respect international norms and practices. In the still-ongoing institution-building process, China has abided by multilateral procedures and confidence building, working together with other stakeholders and adapting its positions to assuage fears of the skeptics and reinforce legitimacy of the bank. As for the surmised inter-organisational rivalry, among the seven projects approved by the bank thus far, four are co-financed with peer institutions (AIIB 2016).

Be that as it may, the driving forces behind the AIIB are multi-faceted and cannot simply spring from pure altruism and public interest considerations. At this stage, there exist plausible arguments about Beijing's self-serving vision to instrumentalise the AIIB to export profit-crushing industrial overcapacity or channel a fraction of massive foreign currency reserves (Ren 2016) or multilateralise opaque bilateralfocused development assistance (Stiglitz 2015). While manifold material incentives can be inextricably involved in such a grandiose project, this article holds that the overriding consideration and leitmotif for China to build the AIIB is political and ideational-searching for a status on a global scale befitting its role as a great power. This is to do with the fact that the funding capacity of the AIIB and particularly the financial contribution of China thereto pale into insignificance in comparison with the sheer scale of Chinese domestic overproduction, reserve stockpile and foreign aid. Predicated on this fundamental premise, the two questions central to this research are: how did China seek status in the case of the AIIB? And relatedly, in what ways is the new lender different from the existing multilateral development banks (MDBs)?

Before proceeding any further, three caveats concerning the scope, case choice and methodology of the study need to be underscored. First, the article discusses mostly how China sought status in the case of the still-new AIIB and is by no means geared towards evaluating the effectiveness of the initiative, for the wider implications of the lender for global governance will probably not be felt in the short term. Second, the AIIB is deliberately chosen and treated as an exemplifying case because it arguably illustrates how China seeks a global status commensurate with its increased economic, political and diplomatic clout. Undoubtedly, the addition of other cases such as the New Development Bank (NDB) — founded by the BRICS (Brazil, Russia, India, China and South Africa) — can be meaningful in terms of illuminating China's international institutional behaviour. But the NDB is more of a collective effort and China's role therein is markedly different from that in the AIIB. Third, this qualitative analysis relies principally on publicly available primary sources including official documents and media outlets, as well as secondary scholarly and policy-oriented works. 
The article will proceed as follows. It starts with a brief review of dominant theoretical discourses on China's swift rise and its major implications for the West and the global system. After reflecting on the main schools of thought and drawing out their analytical limitations, the second part presents the central tenets of the SIT framework, before contextualising it in IR and complementing it with the theoretical construct of institutional innovation for the subsequent case study. The following sections move on to analyse, along the lines of the three standard strategies with additional inputs on institutional innovation, so as to determine the predominant strategy that enabled the AIIB to come to fruition. The concluding remarks summarise the principal findings and cast some light on China's future policy choice in global economic governance.

\section{China's Rise: Prevalent Theoretical Paradigms vs. Social Identity Theory}

So far, much academic and policy-oriented debate has centred on whether the swift ascent of China from the periphery to the centre of global politics will be peaceful (Chen and Pan 2011; Christensen 2006; Friedberg 2005, 2011; Mearsheimer 2001, 2010; Yan 2013, 2014). Three primary IR schools of thought offer contrasting answers. Neo-realists are preoccupied with the 'realties of power politics' and conceive of the global realm as a self-help system. An argument flowing out of realpolitik strategic calculations is that as the relative weight of a new power continues to grow, it inexorably wants to rewrite the rules and establish for itself a new place that brings greater benefits and privileges (Organski and Kugler 1981, 19-23). Dissatisfied with its underprivileged position in the post-1945 institutional foundations, China will in due course disturb the equilibrium of the global system by contesting the system-wide supremacy of the US (Mearsheimer 2001). Such power-based interpretations are backed up by China's military buildup, territorial claims, rejection of Western liberal values and institution-building actions outside the established order.

In contrast to jaundiced realist views, liberal institutionalists suggest that as a function of an ascendant state's integration into the global system, interdependence will shape its preferences in world affairs and push it to respect and comply with the integrative and rules-based international order (Keohane 1998; Keohane and Nye 1987). This is particularly obvious after China's accession to the World Trade Organisation, which has benefited tremendously Chinese trade and investment ties while obliging the world's biggest trading nation to accept the incremental erosion of sovereignty (Harpaz 2010). Constructivists take issue with neo-realist and liberalinstitutionalist explanations, and foreground instead the less tangible and nonmaterial structures of interacting international actors (Checkel 1998; Finnemore 1996; Wendt 1999). They reckon that "States are socialized to want certain things by the international society in which they and the people in them live" (Finnemore 1996, 2). While some scholars find little socialising effects (Kent 2013) or even reverse socialisation $(\mathrm{Pu} 2012)$ in Chinese multilateral diplomacy, others garner 
considerable empirical support for the limited but continuing socialisation of China to take up and internalise select global norms and practices (Johnston 2014).

In the stalemated debate about China's rise, the prevalent theoretical lenses are helpful to varying degrees. Nonetheless, two analytic drawbacks stand out. First, discussions on whether China is a status quo or revisionist power seem to have missed the point, because China can and does revamp the current international order to better serve its expansive needs and interests. Second, the leading strands of IR literature cannot justify in an adequate fashion why China adamantly refuses to accept some international norms and increasingly challenges the global order (contrary to the predictions of liberals and constructivists) but fights shy of completely overhauling or drastically reshaping the global system (at variance with the neo-realist hypotheses). In their search for theoretical parsimony, they tend to either downplay or overlook the salient role of identity, or, more accurately, Beijing's concern about its relative status in the world (Larson 2015, 325).

Recognisably, there is a burgeoning array of research programmes centred on the underexamined status concerns that so pervade the foreign policy of China and other rising states (Larson 2015; Larson and Shevchenko 2003, 2010, 2014). These seminal foundational works invariably conclude that aspiring powers prefer to leverage their distinctive strengths and win an enhanced status in a domain different from that of established powers, rather than competing with or assimilating into the dominant league. While these scholars have furnished persuasive evidence of status concerns in the overarching foreign policy by mostly taking a longitudinal perspective, they have relatively little to say about the causal dynamics for aspiring states like China to choose the strategy of social creativity over that of social mobility or social competition (see infra). More significantly, their conclusion is seldom borne out by examining critically and intensively concrete empirical cases that constitute the rubric of grand status-seeking strategy. To evaluate more adequately the relevance of their scholarship, it would be highly desirable to complement it with compelling case study research and link, where appropriate, individual foreign policy to macro state strategy.

For this purpose, this article looks at an exemplar case encapsulating China's great power aspirations - the AIIB, which brings into striking relief Beijing's resolve to seek a greater status in global economic governance. To probe how China sought status in the case of the AIIB, this study draws on conceptual insights from a vibrant theoretical tradition of social psychology-social identity theory (SIT). Specifically, it employs as a heuristic device the SIT's three standard identity management strategies applied to international relations (IR), in a bid to unpack Beijing's strategic thinking underlying this emblematic status-seeking initiative. In the IR context, SIT posits that an aspiring state may emulate or compete with established powers, or try to achieve national prestige on a new dimension (Larson 2015). To make better sense of the putative value addition of the nascent bank, the article turns to the theoretical construct of institutional innovation, which is operationally defined as "novel, useful, and legitimate change" (Raffaelli and Glynn 2015, 409).

While in line with earlier SIT-inspired works on substantive grounds, this study diverges in two aspects. First, rather than starting out with the presumption that 
rising powers follow the strategy of social creativity and fixating on finding confirming evidence as done previously, this article takes a different track and investigates holistically all three strategies before reaching a conclusion. Second, it deviates from the well-trodden research path by applying the SIT-informed perspective in IR in conjunction with inputs on institutional innovation to extend its analytical rigour to this specific case study. In particular, it brings in institutional innovation as a conceptual tool to better operationalise social creativity-the anticipated dominant strategy. In so doing, the research contributes to: (a) theoretically, applying SIT at the micro level and augmenting it with the construct of institutional innovation in service of analysing individual foreign policy; (b) empirically, substantive discussions on the fledgling institution beyond a face value elusive 'competitive-complementary' dichotomy, and on China's rising ambitions and status-seeking behaviour in global economic governance.

\section{Social Identity Theory: Mobility, Competition, and Creativity}

Developed by social psychologists Henry Tajfel, John Turner and their colleagues in Bristol in the 1970s, SIT has become one of the most prominent and conceptually mature theoretical approaches for studying intergroup relations. For Tajfel (1972, 272), social identity refers to "the individual's knowledge that he belongs to certain social groups together with some emotional and value significance to him of this group membership". Premised on a ubiquitous yearning for positive self-esteem, SIT suggests that individual members want their group to be superior and have greater value connotations in relation to relevant comparison groups. Although scholars diverge over the extent to which the need for positive self-esteem and social identity stimulates intergroup discrimination, there is a near consensus that individuals make use of their group to secure psychologically positive distinctiveness (Abrams and Hogg 1988). As a logical extension, how would individuals react when their group turns out inferior in intergroup comparison and is relegated to the lower rung of a status hierarchy, ${ }^{1}$ and more pertinently, what would they do to change their low subjective status?

Tajfel and Turner (1979, 43-44) laid out three distinctive reactions under contrasting conditions. When the structures and boundaries of intergroup relations are flexible and permeable, individuals will be motivated to disassociate themselves from the erstwhile group and move into a higher-status social group that suits them better. On the contrary, when the structures and boundaries of intergroup relations are rigid, which renders it extremely difficult, if not impossible for individuals to divest themselves of an undesirable group membership, they will prefer group strategies to seek positive distinctiveness for their group by: either directly competing with the reference group in its sphere of superiority (social competition); or creatively comparing their own group to the reference group on other dimensions, redefining negative attributes associated with the in-group as

\footnotetext{
1 For Tajfel and Turner, status is not a scarce resource as power or wealth but results from comparison and comes in various forms.
} 
positive, and changing altogether the reference group (social creativity). While social competition is concerned with the relative position of a group in a particular area and is thus zero sum (Turner 1975), social creativity is about identifying different dimensions to attain higher status and is not necessarily zero sum.

Based on the theoretical constructs rooted in intergroup relations studies, Larson and Shevchenko $(2003,2010)$ articulated the SIT apparatus in IR and appropriated it to analyse the foreign policy of Russia (also Soviet Union) and China in a different light from traditional rationalist accounts. Echoing the core SIT theoretical proposition in intergroup relations that individuals identify themselves with their group and act towards others as group members instead of individuals, they suggest that SIT can be applied to interstate relations. In general, states as a classical social group in the international society are ranked according to a set of value-laden attributes and properties such as population, territory, economy, military, government and culture, among other constituent factors (Larson et al. 2014). When interstate comparison in a status hierarchy reflects adversely on the characteristics and accomplishments of a state-part and parcel of its identity, the state in question will attempt to boost its relative status by following largely, albeit not exclusively, one of the three standard strategies-social mobility, social competition or social creativity. A state may integrate elements of the three strategies in its foreign policy since they are ideal types and not mutually exclusive. Still, there should be a predominant one because "the strategies have different goals and tactics, so that dominance of a particular management strategy alters the state's entire foreign policy" (Larson and Shevchenko 2010, 75).

As shown below (see Table 1), the typology of Larson and Shevchenko is fairly in tune with that of Tajfel and Turner. In the same spirit as ambitious individuals

Table 1 Three identity management strategies (Tajfel and Turner 1979; Larson and Shevchenko 2003, 2010)

\begin{tabular}{|c|c|c|c|}
\hline & $\begin{array}{l}\text { Structural } \\
\text { conditions }\end{array}$ & SIT in intergroup relations & SIT in international relations \\
\hline $\begin{array}{l}\text { Social } \\
\text { mobility }\end{array}$ & $\begin{array}{l}\text { Flexible and } \\
\text { permeable } \\
\text { boundaries } \\
\text { between different } \\
\text { social groups }\end{array}$ & $\begin{array}{l}\text { Disidentify with the erstwhile } \\
\text { group and move into a } \\
\text { higher-status group through } \\
\text { talent, diligence, luck or } \\
\text { whatever other means }\end{array}$ & $\begin{array}{l}\text { Adhere to established rules of } \\
\text { the game, follow common } \\
\text { practices and join } \\
\text { international organisations in } \\
\text { hopes of being admitted into } \\
\text { the elite club }\end{array}$ \\
\hline $\begin{array}{l}\text { Social } \\
\text { competition }\end{array}$ & $\begin{array}{l}\text { Rigid and } \\
\text { impermeable } \\
\text { boundaries } \\
\text { between different } \\
\text { social groups }\end{array}$ & $\begin{array}{l}\text { Compete directly with higher- } \\
\text { status groups in their area of } \\
\text { superiority and seek to } \\
\text { reverse the subjective } \\
\text { position of the in-group and } \\
\text { the out-group }\end{array}$ & $\begin{array}{l}\text { Engage in geopolitical rivalry, } \\
\text { compete for sphere of } \\
\text { influence, promote rival } \\
\text { norms, values and institutions } \\
\text { to equal or replace the } \\
\text { leading powers }\end{array}$ \\
\hline $\begin{array}{l}\text { Social } \\
\text { creativity }\end{array}$ & & $\begin{array}{l}\text { Compare the in-group with the } \\
\text { out-group on new } \\
\text { dimensions, reframe negative } \\
\text { attributes or change the } \\
\text { reference group }\end{array}$ & $\begin{array}{l}\text { Find a distinctive niche, } \\
\text { promote alternative models, } \\
\text { norms and institutions in } \\
\text { global governance to boost } \\
\text { status and prestige }\end{array}$ \\
\hline
\end{tabular}


seeking a more positive identity, aspiring states search for a greater international status. When boundaries of the international society are flexible and permeable, a rising state adopts the social mobility strategy by mimicking the rules and norms of established players to achieve upward mobility and eventually join the elite club. When opportunities for mobility are precluded and structures of the international society are perceived as illegitimate and unstable, states wishing to change their position may resort to the strategy of social competition or social creativity. The former denotes that rising powers go head to head with status quo powers with a view to replacing the dominant group in salient geostrategic and geopolitical areas. The latter relates to the efforts of emerging powers to seek the status and prestige on an alternative ranking scale other than traditional geopolitical power such as promulgating new norms or principles in world politics (Larson 2015).

Insofar as the overall foreign policy is concerned, SIT expects China to follow the social creativity strategy by engaging in favourable comparison with leading powers in a different sphere. Accordingly, it would eschew a drastic overhaul of the multilateral architecture and circumvent the risk of overt competition with the West. Despite its rising ambitions, China's technological and military capabilities remain far inferior to those of the US. In view of the virtually unbridgeable discrepancies in political system and liberal values (Pan 2010, 2012), China has neither the intention nor the capacity to imitate and join the West, whatever the grouping may be. In reality, China has emerged as the undisputed informal leader of emerging and developing countries in regional and multilateral fora, challenging the leadership of established powers in areas like climate action. Moreover, it has made headway in initiating new norms and rules in diplomacy, foreign policy and global governance (Chan 2013; Pu 2012; Yan 2013), and promoting its distinctive model of political economy and development (Breslin 2011). All these seem to validate the SIT theoretical prediction.

Nevertheless, a lingering question is whether the prediction would be equally conclusive if the perspective were switched to individual foreign policy. After all, any critical strategic choice or coordinated grand strategy can be disaggregated to a concrete set of ideas, approaches, objectives and instruments, allowing for the optimum use of limited resources to meet foreign policy goals that are given precedence (Dueck 2008, 1-8). In anticipation of the main findings from empirical observation, this research anticipates that the predominant strategy followed by China in this specific case is indeed social creativity (contra social mobility and social competition). To better apply the identity management strategies, and especially in service of analysing the supposed value-added and distinctiveness of the new development lender in ways that outstrip the ability of SIT, it is both necessary and instructive to look at the theoretical construct of institutional innovation.

\section{Institutional Innovation: Useful, Novel, and Legitimate}

To enrich the SIT with a supplementary model of how social creativity-the anticipated predominant strategy, crystallises in practice-this section theorises institutional innovation as an empirical manifestation of creativity. As a principal 
object of study in the social sciences, institutions can refer to informal social institutions, "a complex of positions, roles, norms and values lodged in particular types of social structures and organising relatively stable patterns of human activity" (Turner 1997, 6). Alternatively, it can manifest in the form of formal entities or structures with defined objectives such as international economic and financial institutions. Notwithstanding its relative stability and durability, both formal and informal institutions change over time and adjust to shifting circumstances. For many institutionalists (Hargrave and Van de Ven 2006; Raffaelli and Glynn 2015), institutional innovation includes both more disruptive or radical innovation (i.e., creating new institutions) and less disruptive or incremental innovation (i.e., modifying existing institutions). Quite often, it is met with contestation and opposition due to the dynamic tensions between institutional stability and change (Hargadon and Douglas 2001, 476).

Among others, Raffaelli and Glynn (2015) proffer a relatively operational conceptualisation and define institutional innovation as "novel, useful, and legitimate change that disrupts, to varying degrees, the cognitive, normative, or regulative mainstays of an organizational field". Institutional innovation, they reasonably infer, is situated at the intersection (or apex) of the three inherently interrelated and mutually reinforcing constitutive components-novelty, usefulness, and legitimacy. Similar to other types of innovation, institutional innovation must be both novel in that it represents a new idea or design with distinguishable features from existing ones and useful in terms of having the capabilities to solve problems or secure goals, particularly in domains where current organisations fall short. More importantly, they stress the overriding consideration for the institutional innovation to be socially, culturally and normatively legitimate, because "the creation, transformation, and diffusion of institutions require legitimacy, a condition whereby other alternatives are seen as less appropriate, desirable, or viable" (Dacin et al. 2002, 47). Accordingly, different strategies are required for an institutional innovation to demonstrate innovativeness, gain legitimacy and be readily accepted. Raffaelli and Glynn (2015, 414-415) put forth two legitimation strategies: bridging from older and more familiar institutions or institutionalised practices to new and creative ones; highlighting new beliefs, issues, needs, problems and opportunities. The first strategy stresses the need for some form of continuity between the past and the present and conformity to prevailing practices, whereas the second accounts for an innovation as a reflexive response to the emergence of new opportunities or critical changes in the general environment.

\section{China's Status-Seeking Strategy: Empirical Evidences from the AIIB}

In what follows, the study combines two streams of the aforementioned theoretical foundations - the three standard strategies applied to IR and pertinent insights into institutional innovation, to expound on how China sought an enhanced international status in the case of the AIIB. More precisely, it looks into how Beijing played by the relevant rules of the game in the institution-building process while accentuating the purported value-added and distinctiveness of an arguably competing initiative. 
Taken together, the ensuing analysis serves to theoretically ascertain whether or not social creativity is preferred over social mobility or social competition, and empirically to bring out further how China sought status in this particular case.

\subsection{Social Mobility: Conformity in the AIIB Institution Building}

Social mobility emphasises the need to respect and emulate the established rules and norms in an ambitious and arduous endeavour to eventually join the elite club. Pertaining to institutional innovation, acting in broad congruence with common standards is vital to the AIIB's legitimacy and credibility, because it bridges from the past to the present and renders the new bank more recognisable, appropriate and legitimately distinctive in the eyes of relevant audiences. Aside from the AIIB's orthodox three-level governance structure, ${ }^{2}$ elements of continuity and compliance can be found in China's evolving positions on a couple of key issues. Overall, China followed international practices and was in favour of multilateralism in the setup of the AIIB, especially in the wake of the unexpected decisions of several Western countries to break ranks with the US and partake in the China-backed initiative.

As regards membership, China initially planned to build a regional bank constituted by Asian and Middle Eastern countries wherein Beijing would contribute up to $50 \%$ of the total capital, which would translate into outright veto power over any decisions (Sun 2015). Unlike the common practice of forming international organisations, preceded usually by rounds of consultations and negotiations between main stakeholders, China unilaterally put forward the AIIB initiative and set the deadline at 31 March 2015 for applying as a prospective founding member (PFM). As late as 6 March 2015, Chinese Finance Minister Lou Jiwei (2015) intimated, "the relative consensus among the twenty-seven members is that we will first open to countries from the region and disregard provisionally the applications of countries outside the region". On 12 March 2015, to the surprise of Washington and Beijing, then Chancellor of the Exchequer George Osborne unveiled the landmark decision of the United Kingdom (UK) to join the AIIB as a PFM without preconditions, citing mostly commercial reasons. Although the UK was openly reprimanded by the US, France, Germany and Italy followed suit and applied in concert for the PFM status within days. The involvement of major European governments not only divided the US, Japan and other Western countries, but also effectively transformed the AIIB in obscurity into a serious multilateral financial venture. In response, Chinese officials thereupon retooled the message and jettisoned the regional emphasis. On 17 March 2015, when speaking of the decision of leading European economies to join the AIIB, Chinese foreign ministry spokesperson Hong Lei ardently stated, "The AIIB is a multilateral development institution that is open and inclusive... The wide participation of countries in and out of the region exemplifies the representativeness of the AIIB" (Chinese Ministry of Foreign Affairs 2015). Given the heavy weight of Japan and South Korea in Asia, Chinese foreign minister Wang Yi conducted consultations on the AIIB with his counterparts from Tokyo and Seoul during their trilateral meeting on 21 March 2015

\footnotetext{
${ }^{2}$ It includes the Board of Governors, the Board of Directors and the management.
} 
(Ren 2016). While South Korea followed European countries and Australia to participate, Japan, alongside its closest ally the US, decided to stay outside. Up till its official launch in mid-January 2016, the bank counted 57 members, including 37 Asian and 20 non-Asian countries. Espousing inclusiveness, the bank remains open to any member of the WB and the ADB (AIIB 2015a, 2). As the AIIB will soon review more than 30 applications to join, the membership is projected to increase to 90, thus outstripping that of the 67-member ADB (People's Daily 2016). A notable example among these candidates is Canada, which applied for membership on 31 August 2016 (Canadian Department of Finance 2016).

Another noteworthy shift relates to the nature of the bank. Early on, the Chinese policy community envisioned the AIIB, with China contributing half of the capital stock, as either a foreign aid agency or a market-oriented commercial bank, both closely associated with China's agenda (Sun 2015). As articulated in an authoritative opinion piece on the Chinese government website, the AIIB can be harnessed to "restructure its foreign aid policy to achieve desired results [and...] serve as a very strong, but positive, external pressure to overcome China's internal political obstacles to further economic, trade and investment liberalization, such as currency internationalization, capital control deregulation, business globalization and financial marketization" (Zhang 2015). Of course, this does not necessarily mean that the earlier visions are irrational, considering the definitive imperative in China to reform its problematic foreign aid policy and domestic economic structure. Rather, linking the presumably multilateral AIIB to Chinese internal agenda would foreshadow and aggravate external concerns about the regime using the bank for its own narrow economic or political objectives. In the face of intense scrutiny from established powers, accommodating participants and staunch holdouts alike, Beijing steered away from the two extremes. Now, the primary function of the AIIB, at least on paper, is neither to channel Chinese foreign aid to underdeveloped Asian economies nor to stimulate domestic economic restructuring, but, as declared in the Articles of Agreement (AOA) of the AIIB, to concentrate on Asian infrastructure with the aim of fostering broad-based sustainable economic and social development in Asia by partnering with current MDBs (AIIB 2015a, 1-2).

With respect to multilateral procedures, eight Chief Negotiators Meetings (CNMs) were convened after the signing of the Memorandum of Understanding on Establishing the AIIB in October 2014. Comprising all the PFMs, the CNMs allowed several rounds of negotiations on the AOA, adopted at the fifth CNM in Singapore, and on key issues as regards the AIIB's shareholding, governance arrangements and future lending activities (AIIB 2015b). In parallel, a select group of seasoned international experts and MDB veterans were asked to prepare the draft AOA and map out the policy framework (Jin 2015a). These channels of consultation and negotiation gave the developed PFMs, particularly European countries, with rich experience in running multilateral organisations, the opportunity to "use their collective bargaining power to negotiate, guide, and shape the bank's AOA from within and enmesh China in a network of international norms and standards" (Sun 2015). That said, the AOA indeed bears apparent similarity to the charters of the WB and the ADB (Wan 2016, 80-82). In this framework, the AIIB is to all intents and purposes compatible with international practices. Moreover, the deliberate 
decision to choose US dollar as the lending currency instead of Chinese RMB reveals that Beijing was receptive to the concern of advanced economies about China using the bank as a vehicle to promote RMB internationalisation and challenge the greenback's dominance in global finance.

As a rising power, China wants to be acknowledged and respected. As an institutional innovation, the AIIB needs to be recognised and accepted. The realisation of both would require a certain degree of adherence to extant practices. To legitimise the nascent lender and win broader support, China adapted its stance on inter alia membership, primary function, shareholding and by implication onevote veto power regarding the AIIB. Undeniably, China's efforts at mitigating relevant concerns and honouring multilateral practices signal conformity and allow external input to shape itself and the institution. In the specific domain of development finance, the mere act of creating a multilateral lender means that China has taken a major step forward to endorse an institutional and multilateral approach. Beijing is not prepared to go all the way and reproduce Western formats unreservedly, however. Thus far, China has shown little enthusiasm to join the traditional donor club-the Development Assistance Committee (DAC) of the Organisation for Economic Cooperation and Development (OECD), wherein developed countries coordinate their aid policies. The China-DAC Study Group, created in 2009 with the express intention of strengthening dialogue and promoting mutual understanding between Chinese officials and OECD member states officials working in the field of development, has proven a failed attempt by the OECD to bring China into the current framework of development cooperation (Ohno 2013). Moreover, as its economic clout continues to grow, China seems intent on becoming a proactive rule shaper or even rule maker in global governance rather than a passive rule taker. Persistent divergences over certain international norms and rising ambitions in the global rule making potentially tilt the rising dragon towards competition.

\subsection{Social Competition: is the AIIB a Competing Initiative?}

Social competition is a strategy preferred by the status-seeking states, particularly when they deem the status hierarchy as illegitimate or unstable. The ultimate goal is to equal and supersede the dominant states in their areas of superiority. Due to the widely perceived illegitimacy of global economic governance institutional underpinnings, competition in such a fast-changing context has been both compelling and ongoing.

Firstly, the AIIB is without doubt a warranted Chinese and Southern answer to their limited influence and the glacial pace of governance reforms within the global economic architecture. For years, major emerging powers, most prominently the BRICS countries have been pressing the West to redistribute voting shares in the WB and the International Monetary Fund (IMF) on the basis of changed realities in the global economy. In purchasing power parity terms, the aggregate economic weight of emerging and developing countries overtook that of their developed counterparts in 2013, growing further to make up 57 percent of global GDP in 2014 (Kynge and Wheatley 2015). Their growing shares notwithstanding, Southern 
countries remain heavily underrepresented with regard to voting power and thus have limited influence in both policy initiatives and lending activities. Moderate reforms in the WB and the IMF were proposed in 2010 to give more power to large emerging economies. Yet, the US Congressional foot-dragging stalled the IMF quota and governance reform package till December 2015. Even in the wake of these reforms, the imbalance has not been substantively ameliorated (OkanoHeijmans and Lanting 2015, 24-27).

As the gradually (semi-) institutionalised global South continues to rise and the economic centre of gravity shifts away from the industrial North to the developing South, the legitimacy of the Bretton Woods system and many other global governance arrangements has been seriously challenged (Keukeleire and Bruyninckx 2011). In fact, China has taken the lead by conceiving channels of its own to redress the asymmetrical paradigm controlled by the West and clamour for greater sway in global economic governance beyond Western claims to leadership, as demonstrated by a wide array of parallel structures initiated either unilaterally by Beijing or jointly with other developing countries (Heilmann et al. 2014). The AIIB is a striking case in point. As an official involved in the talks to found the AIIB noted, "China feels it cannot get anything done in the World Bank or the IMF so it wants to set up its own World Bank that it can control itself" (Anderlini 2014). Without the prospect of substantial reforms resulting from conservative tendencies of the West and bureaucratic inertia of the traditional institutions (Sohn 2015), the AIIB will be imbued with a strong sense of competition and may pose as a rival alternative in the global governance game.

Secondly, the AIIB is set to become a new purveyor of the competing worldview of China and other Southern nations to untie development lending from policy prescriptions. There is no denying that development assistance is no longer a domaine reservé for developed countries sitting on the OECD-DAC. The DAC official development assistance enjoyed near-exclusive dominance in the 1990s, but a handful of non-DAC countries have become consequential aid providers since the 2000s (Kim and Lightfoot 2011). China has transitioned from an aid recipient to a 'net donor' (Chin 2012) and is unquestionably in the vanguard among the non-DAC donors, although the volume of its foreign aid, falling within the scope of SouthSouth cooperation, remains opaque and relatively modest in contrast to heavyweight DAC members (Kitano 2014). But it has been increasing at an accelerating rate in recent years (Kobayashi and Shimomura 2013). Through the Ministry of Commerce, two state policy banks-China Development Bank and China Export-Import Bank-and state-owned enterprises, Beijing, doles out sizeable grants, interest-free loans, concessional loans, and investments to other Southern countries with fewer strings attached as a quid pro quo for political allegiance and enhanced access to strategically important natural resources and export markets (Sanderson and Forsythe 2012).

Due to diverging approaches, external observers have expressed doubts about the expanding operations of rising donors like China and their destabilising effects on the landscape of global development cooperation. Among copious critiques, some criticise China for mercantilist neo-colonialist approach detrimental to Africa's local sustainable development and Western well-intentioned efforts to promote 
democracy and human rights (Tiffen 2014), others lament that the bargaining position of Western donors and the role of the neoliberal economic model or the socalled 'Washington Consensus' have been systematically undermined as emerging donors offer more appealing alternatives to aid-receiving countries (Woods 2008). Even in the face of scathing recurrent criticisms, China remains an outlier of the DAC-dominated aid regime, refusing to subscribe to DAC standards and steering clear of structural adjustment conditions (Bräutigam 2011). With its balance of representation and governance structure, the multilateral AIIB is not expected to merely do the bidding of the most powerful member. But it is bound to approximate its position towards China and other borrowing countries, thereby bringing more pressure to bear on crisis-hit financially constrained traditional donors and urging them to further reform the conditionality-driven framework of development cooperation.

Thirdly, the AIIB features large among a series of Beijing-backed multilateral schemes, stoking controversies about their wider implications for the international system. Among others, in the fall of 2013 China unveiled the grand development framework dubbed in Chinese parlance as the 'Belt and Road' Initiative, complemented and financially supported by the AIIB, the BRICS NDB, the earmarked \$40 billion Silk Road Fund, the China-Eurasia Economic Cooperation Fund and possibly the still-negotiating Shanghai Cooperation Organisation Bank (Chinese State Council 2015). It consists of the 'Silk Road Economic Belt' stretching from China via Central Asia, Middle East to Europe and the '21st-century Maritime Silk Road' connecting China through Southeast and South Asia all the way to the Mediterranean and Africa. Despite its lack of deeper substance as of yet, the signature foreign policy of President Xi Jinping is projected to extend beyond infrastructure construction to encompass financial integration, trade facilitation, cultural exchange and security cooperation between China and countries situated on the belt and the road - a move designed to advance China's strategic imperatives in the neighbourhood and beyond (Johnson 2016). In July 2014 China, alongside fellow BRICS members, created the NDB with a total capital stock of $\$ 100$ billion and the Contingent Reserve Arrangement (CRA) with a currency pool of another $\$ 100$ billion, to which China will contribute $\$ 10$ billion and $\$ 41$ billion, respectively. As a response to the wide governance gaps in the existing financial architecture and chronic financing shortfalls in infrastructure investment (Chin 2014), the Shanghai-based NDB and the CRA can equally threaten Western dominance in global economic governance.

Apart from these two noteworthy initiatives, China has been actively promoting the RMB internationalisation and successfully pushed the IMF to include its currency in the Special Drawing Rights basket as from 1 October 2016 (IMF 2015b), putting RMB on a par with other key international currencies like the US dollar and the euro. Also, Beijing has been advocating the acceleration of negotiations on the Regional Comprehensive Economic Partnership, and the creation of a potential Free Trade Area in Asia-Pacific, seen by many as a counterweight to the Trans-Pacific Partnership (TPP) led by the US (Stephens 2014). In addition, in September 2016 China is due to take on the G20 presidency and will doubtless seek to demonstrate and provide more leadership in global 
economic governance (Chin and Dobson 2016). Although profound reverberations of these forthright activities remain to be seen, together they represent China's unflinching resolve to carve out for itself a bigger role in global economic and financial governance, possibly at the expense of the West.

As one of the most successful China-proposed multilateral initiatives to date, the AIIB is undoubtedly related to the domination of Washington and Tokyo in the WB and the ADB and their reluctance to accord Bejing an international standing corresponding to its increased economic heft (Orr 2016). Also, the new bank alleges to offer a rival model of governance and will likely deliver loans at a faster speed with fewer binding constraints attached (Koh 2015). Nevertheless, does it have the capacity to replace the established players in global development lending? The answer is writ large. In spite of the potential competition that can ensue from the AIIB's growing operations, it is neither able nor intended to become a fully fledged alternative to the WB and the ADB. The new lender boasts $\$ 100$ billion in total authorised capital-equivalent to about half that of the WB and two-thirds that of the ADB (see Table 2), but its level of loan disbursements is, at least initially, unlikely to reach a scale to rival the two dominant players. For the first year of its operations, the AIIB is expected to approve lending of around $\$ 1.2$ billion (Xinhua 2016a), while for the last fiscal year the WB lending stood at $\$ 61$ billion (World Bank 2016) and that of the ADB reached a record-high $\$ 27$ billion (Asian Development Bank 2016). The Chinese authorities professed repeatedly that the AIIB was not intent on upending the present architectural arrangements, but rather to play a complementary role. An authoritative commentary from Chinese Xinhua news agency proclaimed, "The AIIB is by no means a zero-sum game. It serves no one's appetite for hegemony or dominance. Rather, it is a reciprocal, efficient and inclusive platform where member states could seek mutually beneficial cooperation" (Tian 2015). When commenting on the AIIB's political ambitions at Brookings Institution, then President-designate Jin Liqun in charge of shepherding the bank into existence readily dismissed the claim that the lender would undermine the WB and the ADB, and characterised the AIIB as a 'sibling' to the other two lenders (Jin 2015b). Lately, Jin pushed back again on such an assertion at the 2016 Boao Forum for Asia using the analogy of opening a new restaurant alongside present ones (Fung 2016). Beyond political rhetoric, what speaks volumes in substance is that the AIIB officials have been studying the feasibility of co-financing eighteen projects submitted by the WB and eight by the ADB (Orr 2016). As of the time of writing, four out of the seven already-approved projects of the AIIB are cofinanced with existing MDBs and bilateral development agencies such as the WB, ADB, European Bank for Reconstruction and Development (EBRD) and UK Department for International Development (AIIB 2016). Besides, regional and subregional development banks are not at all unprecedented. Apart from the ADB and the EBRD, African Development Bank (AfDB), Andean Development Corporation (CAF), European Investment Bank (EIB) and Inter-American Development Bank (IDB) are notable examples established by the region's countries concerned to address development issues and play an irreplaceable role in regional development financing. 
Table 2 A brief comparison of WB, ADB and AIIB (Kawai 2015, 9; official websites of the three banks)

\begin{tabular}{|c|c|c|c|}
\hline & WB & $\mathrm{ADB}$ & AIIB \\
\hline Formation & 1944 & 1966 & 2015 \\
\hline President & $\begin{array}{l}\text { American (Jim Yong } \\
\text { Kim) }\end{array}$ & $\begin{array}{l}\text { Japanese (Takehiko } \\
\text { Nakao) }\end{array}$ & Chinese (Jin Liqun) \\
\hline Headquarter & Washington D.C., US & Manila, Philippines & Beijing, China \\
\hline Membership & 188 & 67 & 57 \\
\hline Total authorised capital & $\$ 252.8$ billion & $\$ 163.5$ billion & $\$ 100$ billion \\
\hline Average annual lending & 40-50 billion & 13-18 billion & $10-15$ billion \\
\hline Major decision-making & $85 \%$ majority & $75 \%$ majority & $75 \%$ majority \\
\hline Board of directors & 26-member, resident & 12-member, resident & $\begin{array}{l}\text { 12-member, non- } \\
\text { resident }\end{array}$ \\
\hline Largest shareholders & $\begin{array}{l}\text { US (17\%), Japan } \\
(7.9 \%) \text {, China }(5 \%)\end{array}$ & $\begin{array}{l}\text { Japan }(15.7 \%), \text { US } \\
\quad(15.6 \%), \text { China } \\
(6.5 \%)\end{array}$ & $\begin{array}{l}\text { China (26\%), India } \\
\quad(7.5 \%) \text {, Russia } \\
(5.9 \%)\end{array}$ \\
\hline $\begin{array}{l}\text { Combined voting power } \\
\text { of developing countries }\end{array}$ & $\begin{array}{l}\text { Emerging and } \\
\text { developing countries: } \\
42.1 \%\end{array}$ & $\begin{array}{l}\text { Developing member } \\
\text { countries: } 46.8 \%\end{array}$ & $\begin{array}{l}\text { Asian member } \\
\text { countries: } 75 \%\end{array}$ \\
\hline Priority of financing & $\begin{array}{l}\text { Poverty reduction } \\
\text { worldwide }\end{array}$ & $\begin{array}{l}\text { Poverty reduction in } \\
\text { Asia }\end{array}$ & $\begin{array}{l}\text { Asian infrastructure } \\
\text { investment }\end{array}$ \\
\hline
\end{tabular}

\subsection{Social Creativity: the AIIB as a 'Creative' Institutional Innovation}

By contrast with social mobility and social competition, social creativity tries to attract attention and attain preeminence in an area different from that of established powers, shunning geopolitical rivalry. It does so by carving out a distinctive niche or promulgating alternative models, norms and institutions. Drawing on insights from institutional innovation, it appears prima facie that in the case of the AIIB the social creativity strategy unfolds along the triad-usefulness, novelty and legitimacy. Specifically, from the Chinese perspective the AIIB can be an institutional innovation that is useful, novel and legitimate.

Firstly, the AIIB is useful in the sense that it focuses explicitly on tackling the unmet funding shortfall left by the WB and the ADB in Asian infrastructure investment. On many occasions, Chinese authorities highlighted the particular geographical and sectoral priority of the AIIB. In the first-ever official announcement about creating the bank during his maiden trip to Southeast Asia, Xi Jinping (2013) stated the raison d'être of the AIIB is to "help fund the infrastructural development of ASEAN countries and other developing countries in the region". In his speech at the AIIB inauguration ceremony, Xi (2016) reiterated that the Asiacentred bank "has a due role to play to raise the level of infrastructure financing and of economic and social development in the region". At the Munich Security Conference 2016, Chairwoman of the Foreign Affairs Committee of the Chinese National People's Congress Fu Ying (2016a, b) likewise stressed that China proposed new mechanisms (e.g. the AIIB and the 'Belt and Road' Initiative) where 
the current international order falls short, thereby speeding up the provision of quality infrastructure and contributing to the improvement of global governance. Even more to the point, for the Chinese Finance Minister Lou Jiwei (2014), who is now also the Chairman of the Board of Governors of the AIIB, the lender's primary mission is to invest in Asia's quasi-commercial infrastructure projects. If it holds true, this will imply the bulk of the bank's investment, at least at the onset of operations, will fall somewhere between pure profit-seeking investment and nonprofit development lending. This is a substantial difference from the heightened financing focus of the WB and the ADB on poverty reduction.

Over the past several decades, Asia has grown into an economic powerhouse and key driver of global growth. According to the IMF (2015a), Asian economies will continue to outperform the rest of the world, despite the late turmoil. Yet, intraregional development has been uneven and a great many of Asian developing countries are still in dire need of quality infrastructure to further alleviate poverty and sustain economic competitiveness. To tackle the paucity of Asian infrastructure investment, the WB and the ADB have supplied, respectively, $\$ 15$ billion and $\$ 13$ billion per annum (Kawai 2015, 11). But as specified in an oft-cited working report released by the ADB Institute in September 2010, Asia needs infrastructure financing of $\$ 776$ billion (\$747 billion for national and \$29 billion for regional infrastructure) annually during the 2010-2020 period to meet increasing demand in various sectors including transport, water, energy and sanitation (Bhattacharyay 2010). Also, due to the uncertainty of investment returns and the scale of capital requirement and time frame, traditional donors are reluctant to undertake physical infrastructure and invest instead more in social sectors (Chin 2012), thus leaving unmet critical needs of physical infrastructure financing. Even seeing through the prism of Sino-American strategic rivalry, the AIIB can potentially be complementary to US interests in Asia, although Washington's initial response might have suggested a long-standing 'multifaceted containment' strategy to curb China (Etzioni 2016). The AIIB-financed infrastructure projects can become the 'hardware' for trade and investment, whereas the US-underwritten TPP will reduce trade barriers, open up services and harmonise regulations, and thus the 'software' (Dollar 2015). As such, the AIIB does not necessarily have to compete with the WB and the ADB nor shoehorn China-US into zero-sum confrontation. At the same time, it is worth nuancing that the financial capability of the AIIB, while being a helpful boost, is limited. Its annual financing firepower-approximately $\$ 10-15$ billion is merely a drop in the bucket of the $\$ 776$ billion Asia needs each year. The majority of the funding must ultimately come from the private sector such as pension funds and insurers, which the AIIB eyes to leverage and mobilise (Xinhua 2016b). This begs the question: what is the value addition of the AIIB other than the modest amount of additional capital? The possibility for exploring innovations to the current iconic governance models may be the answer one finds within Chinese officialdom.

Secondly, a notable novel feature of the AIIB vis-à-vis the existing MDBs is to provide an alternative governance structure that opens up further prospects for combining efficient operations with high standards. A systemic problem with many MDBs is the huge operational costs and unsatisfactory efficiency caused by slow, risk-averse and overtly bureaucratic procedures. For instance, the WB's resident 
board of directors brings a hefty annual financial cost of $\$ 70$ million and represents an extra layer of management that holds up project preparation (Dollar 2015). For a loan to be delivered, the WB requires no less than four in-country missions during the project preparation phase and four formal review phases prior to loan approval, resulting in an average loan delivery time of 16 months (Humphrey and Michaelowa 2013). Another widely recognised issue with the WB is the undue influence of the US on the overall disbursement of loans. As demonstrated by some fine-grained empirical studies (Fleck and Kilby 2006; Kilby 2009), the WB lending often caters to US trade and foreign policy interests and its programme loans are more likely to be approved after countries adopting pro-US policies, thereby casting a certain amount of doubt on the claimed independence and impartiality of the worldwide development institution.

Having pledged a modern modus operandi of 'clean, lean and green', the AIIB has undertaken several steps in governance structures and lending practices to set itself apart from other MDBs. In particular, two pronounced differences are worth mentioning because they offer a glimpse into the governance innovations avowed by Beijing that are conducive to a felicitous combination of improved efficiency with appropriate safeguards, at least notionally. To minimise costs and streamline operations, the Beijing-based lender will have an unpaid, non-resident board of directors convening at regular intervals and work towards a clear division of responsibilities between the board and the management team in an effort to prevent the former from micromanaging. Testifying to its speedy operation, as of 25 July 2016, slightly over seven months after it officially opened its doors, the bank had approved seven projects and prepared a multi-year pipeline of projects (AIIB 2016). Adding to this is a technocratic approach to de-politicise development financing and disentangle it from the constraint of conditionality, reflecting the view of China and other borrowing countries. Major terms for loans are said to be grounded on practical economic considerations to safeguard the lender's financial position and generate moderate returns on a sustainable pipeline of bona fide bankable projects (Koh 2015), a departure from the unwritten rules advocated and enforced by the WB and the IMF to set specific suites of macroeconomic and institutional reforms as a precondition for loans. In many ways, the AIIB can be deemed a useful foil and complement to the expanding network of MDBs.

However, the devil is in the detail. It remains debatable whether the AIIB can maintain rigorous policies and requisite standards while reducing bureaucracy and foreswearing conditionality. Its environmental and social framework approved in February 2016 has already been criticised by civil society actors not only for its lack of public consultation process, but also for its contents such as lack of oversight mechanism, omission of coal from the exclusion list and adoption of the phased approach $^{3}$ (Kamal and Gallagher 2016). It should be noted nonetheless that projects co-financed by the AIIB with peer institutions are subject to their standards and protocols. In executing the first two joint ventures - a slum renovation in Indonesia with the WB and a road improvement in Tajikistan with the EBRD-the AIIB seems to be attentive to environmental externalities (The Economist 2016). At the

\footnotetext{
${ }^{3}$ It allows environmental and social impacts on indigenous groups to be assessed after project approval.
} 
first annual meeting, Jin restated the lender's commitment to cooperation with existing MDBs, governance, efficiency, safeguards, green investments and publicprivate partnerships, as well as its aspiration to become "one of the leading multilateral financial institutions for cutting-edge infrastructure investments" (Jin 2016). In any case, the reputation of the new institution will not arise from paying lip service to innovative features, but rest on its ability, buttressed by in-house expertise, on-the-ground capabilities and a strong-enough governance structure (Kahn 2015), to live up to the lofty expectations and make good on the grandiose rhetoric in actual undertakings.

Thirdly, the AIIB is legitimate as it provides in principle long-awaited ownership for the Global South in global finance, apart from being multilateral in nature and useful in delivering an inadequate global public good. For the moment, there are about $20 \mathrm{MDBs}$ across the world including inter alia the WB, ADB, AfDB, EBRD and IDB. But most if not all, MDBs with a respectable amount of assets were created and remain dominated by the West, giving rather an insufficient voice to developing countries. For this reason, the AIIB has a rightful place to fill. As the official news agency Xinhua (2015) puts it, "As the increasing importance of emerging markets changes the landscape of a global economic order that has long been dominated by advanced economies, they also want a new institution that best serves their own interests. The AIIB answers that call". In a sense, the AIIB is poised to become an influential multilateral institution truly owned by the Southern countries due to its allocation of voting power securing strong representation of developing countries. The bank's charter (AIIB 2015a, 4) mandates that no less than $75 \%$ of the total authorised capital stock and by implication, 9 out of 12 members in the board of directors, must come from regional members, thereby giving the driving seat to Asian developing economies. In agreement with the mandate, the board is currently composed of nine regional and three non-regional directors. ${ }^{4}$ Adding to the strong regional representation, BRICS powerhouses China, India and Russia counting an overwhelming aggregate voting share of nearly 40 percent are the most influential players (see Table 2). By bringing such a cluster of emerging and developing countries under a single tent, the AIIB may ipso facto become an upgraded platform for South-South cooperation.

Of equal importance in this vein is the privileged position China enjoys in decision-making on the basis of its voting shares. Despite forgoing the outright veto power in day-to-day decisions, the world's second largest economy remains the largest shareholder and has a whopping voting share of $26 \%$. As stipulated in the AIIB charter, major decisions (e.g. authorised capital and voting rights, operational and financial policies, composition of board of directors and appointment of president) require a super majority of "an affirmative vote of two-thirds of the total number of governors, representing not less than three-fourths of the total voting power of the member" (AIIB 2015a, 17). As such, China virtually enjoys veto power over critical issues as circumstances warrant. Having said that, a simple majority will suffice over matters including individual project approvals. Besides,

\footnotetext{
${ }^{4}$ Nine regional directors are from Australia, China, India, Indonesia, South Korea, Russia, Thailand and Turkey, and three non-regional ones from Brazil, Germany, and UK.
} 
according to Jin Liqun, China plans neither to exercise its de facto veto nor to retain it by increasing the super majority when its voting power is diluted after the entry of new members, as opposed to what the US did with the WB (Fu 2016a, b). This is sensible because a dominant veto-casting Beijing will blemish the hard-won stature of the multilateral, worsen the oft-alluded concern about China's hidden agenda and ultimately discount the success of its status seeking.

\section{Conclusions}

This article situates the AIIB in the broader context of China's unwavering search for great-power status on the world stage. By employing SIT to enquire into the developments leading up to the advent of the AIIB and its early operation, it makes the case that social creativity is indeed the strategy preferred by China in the politics of this quintessential status-seeking initiative. Of course, the jury is still out on whether the new lender will be complementary or competitive. Nonetheless, the Chinese government mustered enormous political capital to reassure the West that the Beijing-based bank-an institutional innovation partly conceived out of simmering frustrations at the current global governance structures and unequivocal imperatives to contest for greater say therein-is a useful, novel and legitimate addition. Admittedly, strands of mobility and competition are present in China's sweeping conformity to prevailing practices and its pervasive quest for bigger influence, but they have proven inadequate when measured against the yardstick of either Beijing's intention to join the elite club or the AIIB's capability to overturn the dominant players. Hence, theoretically this case study of the AIIB substantiates the validity of the SIT-informed perspective on the preferred status-seeking strategy of rising powers and extends its explanatory reach to critically and intensively analysing individual foreign policy. Still, this analysis, honing in on one emblematic case in global economic governance, is in many ways just a beginning for a largely underresearched agenda on status seeking at the micro level. Further empirical research in other issue areas needs to be done so as to lend more weight to the SIT scholarship in IR.

Empirically, three findings yielded from this qualitative analysis can be indicative of the underlying rationale and strategic thinking to seek a greater status across a growing range of China-proposed alternative structures. The first and most obvious is that the new bank demonstrates further China's dual-track approach to global governance. To create a more favourable environment wherein rising powers can enhance status and influence, China has started building novel institutions in parallel with its active push to modify the system from within. Second, in the setup of the AIIB, it can be argued that China largely respected international norms, rules and practices to allay doubt and gain legitimacy. Beijing was amenable to the concerns of established powers and modified its stance accordingly on a string of key issues. Third and finally, from the Chinese perspective, the role of the multilateral lender, as other structures proposed by Beijing, is not competitive or confrontational but critical and complementary. It serves as a helpful, legitimately distinctive alternative rather than aiming to undercut existing institutions. Following 
positive experiences with the AIIB, there is little doubt that China will proceed with similar strategic thinking in the near future in a bid to boost its standing as a great power relative to leading powers in the global economic landscape. When that happens, it would be useful to expand the study to incorporate similar cases so as to better comprehend China's international institutional behaviour.

Acknowledgments The author would like to thank his supervisor Professor Stephan Keukeleire, fellow colleagues in the Leuven International and European Studies Institute, the editor and the anonymous reviewers for their perceptive comments. This work has been carried out with financial support from the China Scholarship Council.

\section{References}

Abrams, Dominic, and Michael A. Hogg. 1988. Comments on the motivational status of self-esteem in social identity and intergroup discrimination. European Journal of Social Psychology 18(4): 317-334.

Anderlini, Jamil. 2014. China expands plans for World Bank rival. Financial Times. http://www.ft.com/ intl/cms/s/0/b1012282-fba4-11e3-aa19-00144feab7de.html. Accessed 2 Mar 2016.

Asian Development Bank. 2016. ADB annual report 2015. http://www.adb.org/documents/adb-annualreport-2015. Accessed 2 Aug 2016.

Asian Infrastructure Investment Bank (AIIB). 2015a. Articles of Agreement. http://www.aiib.org/ uploadfile/2016/0202/20160202043950310.pdf. Accessed 5 Mar 2016.

Asian Infrastructure Investment Bank (AIIB). 2015b. Report on the Articles of Agreement of the Asian Infrastructure Investment Bank. http://euweb.aiib.org/uploadfile/2016/0204/20160204112514995. pdf. Accessed 3 Mar 2016.

Asian Infrastructure Investment Bank (AIIB). 2016. Projects. http://euweb.aiib.org/html/PROJECTS. Accessed 22 Aug 2016.

Bhattacharyay, Biswa N. 2010. Estimating demand for infrastructure in energy, transport, telecommunications, water and sanitation in Asia and the Pacific: 2010-2020. ADBI Working Paper 248. Tokyo: Asian Development Bank Institute.

Bräutigam, Deborah. 2011. Aid 'with Chinese characteristics': Chinese foreign aid and development finance meet the OECD-DAC aid regime. Journal of International Development 23(5): 752-764.

Breslin, Shaun. 2011. The 'China model' and the global crisis: from Friedrich list to a Chinese mode of governance? International Affairs 87(6): 1323-1343.

Callaghan, Mike, and Paul Hubbard. 2016. The Asian Infrastructure Investment Bank: multilateralism on the Silk Road. China Economic Journal 9(2): 116-139.

Canadian Department of Finance. 2016. Canadians will benefit from Canada's membership in the Asian Infrastructure Investment Bank: Morneau. http://www.fin.gc.ca/n16/16-106-eng.asp. Accessed 31 Aug 2016.

Chan, Gerald. 2013. China faces the world: making rules for a new order? Journal of Global Policy and Governance 2(1): 105-119.

Checkel, Jeffrey. 1998. The constructive turn in international relations theory. World Politics 50(02): 324-348.

Chen, Zhimin, and Zhongqi Pan. 2011. China in its neighbourhood: a 'middle kingdom' not necessarily at the centre of power. The International Spectator 46(4): 79-96.

Chen, Zhimin. 2014. Zhongguo de waijiao chuangxin shifou xuyao waijiao gemin [Whether China's diplomatic innovation needs diplomatic revolution]. Shijie Jingji yu Zhengzhi [World Economy and Politics] 12: 37-51.

Chin, Gregory T. 2012. China as a 'net donor': tracking dollars and sense. Cambridge Review of International Affairs 25(4): 579-603.

Chin, Gregory T. 2014. The BRICS-led development bank: purpose and politics beyond the G20. Global Policy 5(3): 366-373.

Chin, Gregory T. 2016. Asian Infrastructure Investment Bank: governance innovation and prospects. Global Governance 22(1): 11-26. 
Chin, Gregory T., and Hugo Dobson. 2016. China's presidency of the G20 Hangzhou: on global leadership and strategy. Global Summitry 1(2): 151-170.

Chinese Ministry of Foreign Affairs. 2015. Foreign ministry spokesperson Hong Lei's regular press conference on 17 March 2015. http://www.fmprc.gov.cn/mfa_eng/xwfw_665399/s2510_665401/ t1246361.shtml. Accessed 13 Apr 2016.

Chinese State Council. 2015. Full text: action plan on the Belt and Road initiative. http://english.gov.cn/ archive/publications/2015/03/30/content_281475080249035.htm. Accessed 5 July 2016.

Christensen, Thomas J. 2006. Fostering stability or creating a monster? The rise of China and US policy toward East Asia. International Security 31(1): 81-126.

Dacin, M.Tina, Jerry Goodstein, and W. Richard Scott. 2002. Institutional theory and institutional change: introduction to the special research forum. Academy of Management Journal 45(1): 45-56.

Dollar, David. 2015. China's rise as a regional and global power: the AIIB and the One Belt One Road. Washington D.C.: Brookings Institution. http://www.brookings.edu/research/papers/2015/07/chinaregional-global-power-dollar. Accessed 2 Mar 2016.

Dueck, Colin. 2008. Reluctant crusaders: power, culture, and change in American grand strategy. Princeton: Princeton University Press.

Elek, Andrew. 2014. The potential role of the Asian Infrastructure Investment Bank. East Asia Forum. http://www.obela.org/system/files/AsianBank_AElek_0.pdf. Accessed 5 July 2016.

Etzioni, Amitai. 2016. The Asian Infrastructure Investment Bank: a case study of multifaceted containment. Asian Perspective 40(2): 173-196.

Finnemore, Martha. 1996. National interests in international society. Ithaca: Cornell University Press.

Fleck, Robert, and Christopher Kilby. 2006. World Bank independence: a model and statistical analysis of US influence. Review of Development Economics 10(2): 224-240.

Friedberg, Aaron L. 2005. The future of US-China relations: is conflict inevitable? International Security 30(2): 7-45.

Friedberg, Aaron L. 2011. A contest for supremacy: China, America, and the struggle for mastery in Asia. New York: WW Norton \& Company.

Fu, Jing. 2016. AIIB chief rules out China veto power. China Daily. http://europe.chinadaily.com.cn/ business/2016-01/27/content_23273436.htm. Accessed 7 Mar 2016.

Fu, Ying. 2016. Putting the order(s) shift in perspective. Speech at the 52nd Munich Security Conference. https://www.securityconference.de/en/activities/munich-security-conference/msc-2016/speeches/ speech-by-fu-ying. Accessed 2 Apr 2016.

Fung, Esther. 2016. AIIB not looking for trouble, president says. The Wall Street Journal. http://www. wsj.com/articles/aiib-not-looking-for-trouble-president-says-1458896738. Accessed 5 May 2016.

Greenwood, Larry. 2016. AIIB: now comes the hard part. Washington D.C.: Center for Strategic and International Studies. https://www.csis.org/analysis/aiib-now-comes-hard-part. Accessed 1 Mar 2016.

Hargadon, Andrew B., and Yellowlees Douglas. 2001. When innovations meet institutions: Edison and the design of the electric light. Administrative Science Quarterly 46(3): 476-501.

Hargrave, Timothy J., and Andrew H. Van de Ven. 2006. A collective action model of institutional innovation. Academy of Management Review 31(4): 864-888.

Harpaz, Marcia Don. 2010. Sense and sensibilities of China and WTO dispute settlement. Journal of World Trade 44(6): 1155-1186.

Heilmann, Sebastian, Moritz Rudolf, Mikko Huotari, and Johannes Buckow. 2014. China's shadow foreign policy: parallel structures challenge the established international order. MERICS China Monitor 18. Berlin: Mercator Institute for China Studies.

Humphrey, Chris, and Katharina Michaelowa. 2013. Shopping for development: multilateral lending, shareholder composition and borrower preferences. World Development 44: 142-155.

Humphrey, Christopher. 2015. Developmental revolution or Bretton Woods revisited?. London: Overseas Development Institute.

International Monetary Fund. 2015a. Regional economic outlook: Asia and Pacific stabilizing and outperforming other regions. http://www.imf.org/external/pubs/ft/reo/2015/apd/eng/areo0415.htm. Accessed 12 Mar 2016.

International Monetary Fund. 2015b. Chinese RMB to be included in IMF's special drawing right basket. http://www.imf.org/external/pubs/ft/survey/so/2015/new120115a.htm. Accessed 12 Mar 2016.

Jin, Liqun. 2015a. AIIB to benefit Asia and beyond. China Daily. http://www.chinadaily.com.cn/opinion/ 2015-12/28/content_22836923.htm. Accessed 4 Apr 2016. 
Jin, Liqun. 2015b. Building Asia's new bank. Speech at Brookings Institution. https://www.brookings. edu/events/building-asias-new-bank-an-address-by-jin-liqun-president-designate-of-the-asian-infra structure-investment-bank. Accessed 4 Apr 2016.

Jin, Liqun. 2016. President's opening statement 2016 annual meeting of the Board of Governors Asian Infrastructure Investment Bank. http://euweb.aiib.org/html/2016/NEWS_0625/121.html. Accessed 12 July 2016.

Johnson, Christopher K. 2016. President Xi Jinping's "Belt and Road" initiative. Washington D.C.: Center for Strategic and International Studies. https://www.csis.org/analysis/president-xi-jinping'sbelt-and-road-initiative. Accessed 5 Apr 2016.

Johnston, Alastair Iain. 2014. Social states: China in international institutions, 1980-2000. Princeton: Princeton University Press.

Kahn, Robert. 2015. Interview: a bank too far? New York: Council on Foreign Relations. http://www.cfr. org/global-governance/bank-too-far/p36290. Accessed 2 Mar 2016.

Kamal, Rohini, and Kevin P. Gallagher. 2016. China goes global with development banks. London: Bretton Woods Project. http://www.brettonwoodsproject.org/2016/04/20508. Accessed 3 July 2016.

Kawai, Masahiro. 2015. Asian Infrastructure Investment Bank in the evolving international financial order. In Asian Infrastructure Investment Bank: China as responsible stakeholder?, ed. Daniel Bob, 5-26. Washington D.C.: Sasakawa Peace Foundation USA.

Kent, Ann. 2013. China, the United Nations, and human rights: the limits of compliance. Philadelphia: University of Pennsylvania Press.

Keohane, Robert O. 1998. International institutions: can interdependence work? Foreign Policy 100: 82-194.

Keohane, Robert O., and Joseph S. Nye. 1987. Power and interdependence revisited. International Organization 41(04): 725-753.

Keukeleire, Stephan, and Hans Bruyninckx. 2011. The European Union, the BRICs, and the emerging new world order. In International relations and the European Union, 2nd ed, ed. Christopher Hill, and Michael Smith, 380-403. Oxford: Oxford University Press.

Kilby, Christopher. 2009. The political economy of conditionality: an empirical analysis of World Bank loan disbursements. Journal of Development Economics 89(1): 51-61.

Kim, Soyeun, and Simon Lightfoot. 2011. Does 'DAC-ability' really matter? The emergence of non-DAC donors: introduction to policy arena. Journal of International Development 23(5): 711-721.

Kitano, Naohiro. 2014. China's foreign aid at a transitional stage. Asian Economic Policy Review 9(2): 301-317.

Kobayashi, Takaaki, and Yasutami Shimomura. 2013. Aid volume in a historical perspective. In $A$ study of China's foreign aid: an Asian perspective, ed. Yasutami Shimomura, and Hideo Ohashi, 46-57. Basingstoke: Palgrave Macmillan.

Koh, Guiqing. 2015. Exclusive: China's AIIB to offer loans with fewer strings attached. Reuters. http:// www.reuters.com/article/us-aiib-china-loans-idUSKCNOR14UB20150901. Accessed 8 Mar 2016.

Kynge, James, and Jonathan Wheatley. 2015. Emerging markets: redrawing the world map. Financial Times. http://www.ft.com/intl/cms/s/2/4a915716-39dc-11e5-8613-07d16aad2152.html. Accessed 12 Mar 2016.

Larson, Deborah Welch, and Alexei Shevchenko. 2003. Shortcut to greatness: the new thinking and the revolution in Soviet foreign policy. International Organization 57(01): 77-109.

Larson, Deborah Welch, and Alexei Shevchenko. 2010. Status seekers: Chinese and Russian responses to US primacy. International Security 34(4): 63-95.

Larson, Deborah Welch, and Alexei Shevchenko. 2014. Managing rising powers: the role of status concerns. In Status in world politics, eds. Tarzha Varkey Paul, Deborah Welch Larson, and William Wohlfort, 33-70. Cambridge: Cambridge University Press.

Larson, Deborah Welch, Tarzha Varkey Paul, and William Wohlfort. 2014. Status and world order. In Status in world politics, eds. Tarzha Varkey Paul, Deborah Welch Larson, and William Wohlfort, 3-32, Cambridge: Cambridge University Press.

Larson, Deborah Welch. 2015. Will China be a new type of great power? The Chinese Journal of International Politics 8(4): 323-348.

Liao, Rebecca. 2015. Out of the Bretton Woods: how the AIIB is different. Foreign Affairs. https://www. foreignaffairs.com/articles/asia/2015-07-27/out-bretton-woods. Accessed 6 May 2016.

Lou, Jiwei. 2014. Yi PPP moshi jiejue yatai diqu jijian rongzi quekou [Using PPP to solve infrastructure financing gaps in Asia-Pacific]. Caixin. http://international.caixin.com/2014-10-23/100742118.html. Accessed 21 Mar 2016. 
Lou, Jiwei. 2015. Yatouhang chuangshi chengyuanguo zige queren sanyue di jiezhi [AIIB founding membership status confirmation ends at the end of March]. Xinhuanet. http://news.xinhuanet.com/ politics/2015lh/2015-03/06/c_1114552782.htm. Accessed 1 Mar 2016.

Mearsheimer, John J. 2001. The tragedy of great power politics. New York: WW Norton \& Company.

Mearsheimer, John J. 2010. The gathering storm: China's challenge to US power in Asia. The Chinese Journal of International Politics 3(4): 381-396.

Nye, Joseph S. 2013. Work with China, don't contain it. The New York Times. http://www.nytimes.com/ 2013/01/26/opinion/work-with-china-dont-contain-it.html. Accessed 21 Apr 2016.

Ohno, Izumi. 2013. China's foreign aid and international aid community: from the perspectives of traditional donors and Africa. In A study of China's foreign aid: an Asian perspective, ed. Yasutami Shimomura, and Hideo Ohashi, 193-216. Basingstoke: Palgrave Macmillan.

Okano-Heijmans, Maaike, and Daniel Lanting. 2015. Europe's response to China's activism: balancing hope and fear in the new age of global economic governance. The Hague: Clingendael Netherlands Institute of International Relations.

Organski, Abramo F.K., and Jacek Kugler. 1981. The war ledger. Chicago: University of Chicago Press.

Orr, Robert M. 2016. The Asian Development Bank and the Asian Infrastructure Investment Bank: conditional collaboration? Washington D.C.: Center for Strategic and International Studies. https:// www.csis.org/analysis/pacnet-39-asian-development-bank-and-asian-infrastructure-investment-bankconditional. Accessed 22 Aug 2016.

Pan, Zhongqi (ed.). 2012. Conceptual gaps in China-EU relations: global governance, human rights and strategic partnerships. Basingstoke: Palgrave Macmillan.

Pan, Zhongqi. 2010. Managing the conceptual gap on sovereignty in China-EU relations. Asia Europe Journal 8(2): 227-243.

People's Daily. 2016. AIIB to increase to 90 member states. China.org.cn. http://www.china.org.cn/ business/2016-08/27/content_39176921.htm. Accessed 28 Aug 2016.

Pollack, Jonathan. 2015. Joining the club: how will the United States respond to AIIB's expanding membership? Washington D.C.: Brookings Institution. http://www.brookings.edu/blogs/order-fromchaos/posts/2015/03/17-joining-the-club-aiib-pollack. Accessed 5 Mar 2016.

$\mathrm{Pu}$, Xiaoyu. 2012. Socialisation as a two-way process: emerging powers and the diffusion of international norms. The Chinese Journal of International Politics 5(4): 341-367.

Raffaelli, Ryan, and Mary Ann Glynn. 2015. Institutional innovation: novel, useful, and legitimate. In The Oxford handbook of creativity, innovation, and entrepreneurship, eds. Christina Shalley, Michael A. Hitt, and Jing Zhou, 407-420. Oxford: Oxford University Press.

Reisen, Helmut. 2015. Will the AIIB and the NDB help reform multilateral development banking? Global Policy 6(3): 297-304.

Ren, Xiao. 2016. China as an institution-builder: the case of the AIIB. The Pacific Review 29(3): 435-442.

Renard, Thomas. 2015. The Asian Infrastructure Investment Bank (AIIB): China's new multilateralism and the erosion of the West. Security Policy Brief 63. Brussels: Egmont Royal Institute for International Relations.

Sanderson, Henry, and Michael Forsythe. 2012. China's superbank. Debt, oil and influence: how China Development Bank is rewriting the rules of finance. New Jersey: Wiley.

Shapiro, Jeremy. 2015. The Chinese foray into global governance. Washington D.C.: Brookings Institution. http://www.brookings.edu/blogs/order-from-chaos/posts/2015/04/01-china-global-governanceshapiro. Accessed 6 Apr 2016.

Sohn, Injoo. 2015. AIIB: a plank in China's hedging strategy. Washington D.C.: Brookings Institution. https://www.brookings.edu/opinions/aiib-a-plank-in-chinas-hedging-strategy. Accessed 12 Mar 2016.

Stephens, Hugh. 2014. TPP or FTAAP: what it means for US and the Asia-Pacific. China US Focus. http://www.chinausfocus.com/finance-economy/tpp-or-ftaap-what-it-means-for-us-and-the-asiapacific-region. Accessed 12 May 2016.

Stiglitz, Joseph E. 2015. Asia's multilateralism. Project Syndicate. https://www.project-syndicate.org/ commentary/china-aiib-us-opposition-by-joseph-e-stiglitz-2015-04. Accessed 2 June 2016.

Subacchi, Paola. 2015. The AIIB is a threat to global economic governance. Foreign Policy. http:// foreignpolicy.com/2015/03/31/the-aiib-is-a-threat-to-global-economic-governance-china. Accessed 2 Aug 2016. 
Sun, Yun. 2015. China and the changing Asian Infrastructure Investment Bank. Washington D.C.: Center for Strategic and International Studies. http://csis.org/publication/pacnet-43-china-and-changingasian-infrastructure-bank. Accessed 4 Mar 2016.

Swaine, Michael D. 2010. Perceptions of an assertive China. China Leadership Monitor 32(2): 1-19.

Tajfel, Henri, and John C. Turner. 1979. An integrative theory of intergroup conflict. In The social psychology of intergroup relations, ed. William G. Austin, and Stephan Worchel, 33-47. Monterey: Brooks-Cole.

Tajfel, Henri. 1972. Social categorisation. In Introduction à la psychologie sociale, ed. Serge Moscovici, 272-302. Paris: Larousse.

The Economist. 2016. The infrastructure of power. http://www.economist.com/news/finance-andeconomics/21701494-reasons-be-enthusiastic-about-chinas-answer-world-bank-infrastructure. Accessed 22 Aug 2016.

Tian, Dongdong. 2015. Commentary: Washington, what are you waiting for? Xinhuanet. http://news. xinhuanet.com/english/2015-03/18/c_134076605.htm. Accessed 22 Mar 2016.

Tiffen, Adam. 2014. The new-neocolonialism in Africa. Global Policy. http://www.globalpolicyjournal. com/blog/19/08/2014/new-neo-colonialism-africa. Accessed 20 Aug 2016.

Turner, John C. 1975. Social comparison and social identity: some prospects for intergroup behaviour. European Journal of Social Psychology 5(1): 1-34.

Turner, Jonathan H. 1997. The institutional order: economy, kinship, religion, polity, law, and education in evolutionary and comparative perspective. New York: Longman Publishing Group.

Ujvari, Balazs. 2016. The global strategy: reinvigorating the EU's multilateral agenda? Security policy brief, vol. 69. Brussels: Egmont Royal Institute for International Relations.

Wan, Ming. 2016. The Asian Infrastructure Investment Bank: the construction of power and the struggle for the East Asian international order. New York: Palgrave Macmillan.

Wendt, Alexander. 1999. Social theory of international politics. Cambridge: Cambridge University Press.

Woods, Ngaire. 2008. Whose aid? Whose influence? China, emerging donors and the silent revolution in development assistance. International Affairs 84(6): 1205-1221.

World Bank. 2016. Press release: World Bank Group support tops $\$ 61$ billion in fiscal year 2016. http:// www.worldbank.org/en/news/press-release/2016/07/12/world-bank-group-support-tops-61-billionin-fiscal-year-2016. Accessed 22 Aug 2016.

Xi, Jinping. 2013. Deepen reform and opening up and work together for a better Asia Pacific. Speech at the APEC Economic Leaders' Meeting. http://www.fmprc.gov.cn/mfa_eng/topics_665678/ xjpfwynmlxycx21apec_665682/t1088517.shtml. Accessed 1 Mar 2015.

Xi, Jinping. 2016. Speech at the inauguration ceremony of the Asian Infrastructure Investment Bank in Beijing. http://news.xinhuanet.com/english/china/2016-01/16/c_135015661.htm. Accessed 1 Mar 2016.

Xing, Yuqing. 2016. The Asian Infrastructure Investment Bank and China's role in regional economic governance. East Asian Policy 8(02): 25-36.

Xinhua. 2015. China voice: the call of times. Xinhuanet. http://news.xinhuanet.com/english/2015-06/29/ c_134366132.htm. Accessed 2 Mar 2016.

Xinhua. 2016a. AIIB cooperates with World Bank, ADB, to approve first batch of projects in June. Xinhuanet. http://news.xinhuanet.com/english/2016-04/14/c_135277902.htm. Accessed 24 Aug 2016.

Xinhua. 2016b. AIIB eyes co-financing with pension funds, insurance. Xinhuanet. http://news.xinhuanet. com/english/2016-08/26/c_135636578.htm. Accessed 27 Aug 2016.

Yan, Xuetong. 2013. New values for new international norms. China International Studies 38(1): 19-26.

Yan, Xuetong. 2014. From keeping a low profile to striving for achievement. The Chinese Journal of International Politics 7(2): 153-184.

Zhang, Lijuan. 2015. The AIIB: making room for China in the global economy. China.org.cn. http:// www.china.org.cn/opinion/2015-04/20/content_35365944_2.htm. Accessed 2 Mar 2016.

Hai Yang is a doctoral candidate at the Leuven International and European Studies Institute of the KU Leuven (University of Leuven, Belgium). 